\title{
Comparative screening of anti-sickling reported and traditional herbs found in Chhattisgarh
}

\author{
Deepak K Dash ${ }^{1}$, Anil Sahu ${ }^{2}$, Rajnikant Panik ${ }^{3}$, Kaushlesh Mishra ${ }^{4}$, Pankaj Kashyap ${ }^{5}$, Vaibhav Tripathi6 ${ }^{* *}$ \\ ${ }^{1}$ Principal, ${ }^{2-6}$ Assistant Professor, Royal College of Pharmacy, Raipur, Chhattisgarh, India
}

*Corresponding Author: Vaibhav Tripathi

Email: vaibhu.07@gmail.com

\begin{abstract}
Sickle cell anaemia (SCA) has been recognized as a serious genetic disorder throughout the World. This genetic abnormality arises at the sixth position of $\beta$-chain of haemoglobin, where amino acid valine is replaced by glutamic acid. SCA has already been announced as an endemic in Chhattisgarh state. Chhattisgarh is well known for its enriched source of herbal plants. People use herbal system of medicine for the management of sickle cell anaemia. Folk healers have sound knowledge of herbal and food plants and they have been practicing such nutraceuticals on sickle anaemic patients for many years. Present review is all about reported and traditional herb. Moreover, we have performed phytochemical screening of some traditional herbs which are being used by the healer's. on the basis of screening data we have compared the bio-constituents of both reported and traditional herbs. Thus, the present work has encompassed review as well as comparative data. This paper will be beneficial for the new budding researchers for the further assessment of such plants for their anti-sickling activity.
\end{abstract}

Keywords: Sickle cell anaemia, Endemic, Traditional healers, Nutraceuticals, Phytochemical screening.

\section{Sickle Cell Anaemia}

This disease was medically recognized about one hundred years ago. Formerly, it was considered as hematological infection. Modernization in medical science has brought about the new facts and scientific data about sickle cell anaemia (SCA) and proved it is a genetic disorder associated with abnormality in red blood cells.

At present millions of peoples are being reported sickle patients globally. The numbers of patients are increasing day by day. At molecular level, it has been found that SCA is caused due the substitution of valine (a sort of amino acid) by glutamic acid at the sixth position of beta chain of haemoglobin $(\mathrm{Hb})$. On the other hand, many scientific studies have revealed that malaria also acts as a trigger factor for sickle cell anaemia. Malaria attacks the red blood cells in a destructive manner. Maleria has already been declared as an endemic in most of the region of the World. In such areas, the red blood cells gradually change its shape and size in order to protect itself against malaria parasite. It is due to this reason the cells become sickle shaped. This phenomenon brings about the sickle cell anaemia. This phenotype modification changes the genotype constitution of the human over a long period of time. It is also known as mutation. ${ }^{1}$

Consequently the normal haemoglobin $(\mathrm{Hb} \mathrm{N})$ becomes abnormal sickle haemoglobin ( $\mathrm{Hb} \mathrm{S}$ ).

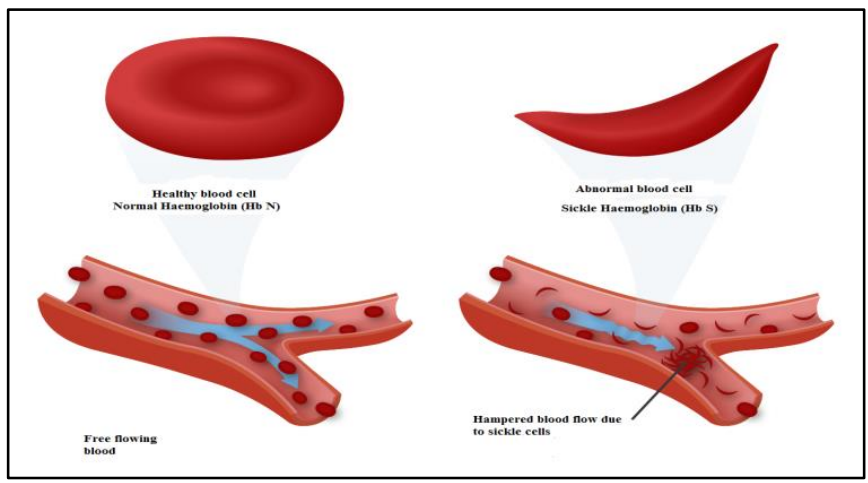

Fig. 1: Structure of blood cells and blood flow

Such abnormality in haemoglobin affects the shape of red blood cells. Physically the oval shape of normal blood cells converts into sickle shape. Furthermore, the life span of red blood cells is reduced to about 10 to 20 days instead of 90 to 120 days. It happens because of the deformity of red blood cells consequently cells tend to burst. This unusual condition brings about anemia. Moreover, converted 
abnormal shape causes severe pathological changes (Figure 1), which are manifested in the form of characteristic symptoms of sickle cell anaemia.

Sickle cell anaemia (SCA) is a genetic disorder; it means the prevalence of SCA can be predicted with the help of genetic family chart.

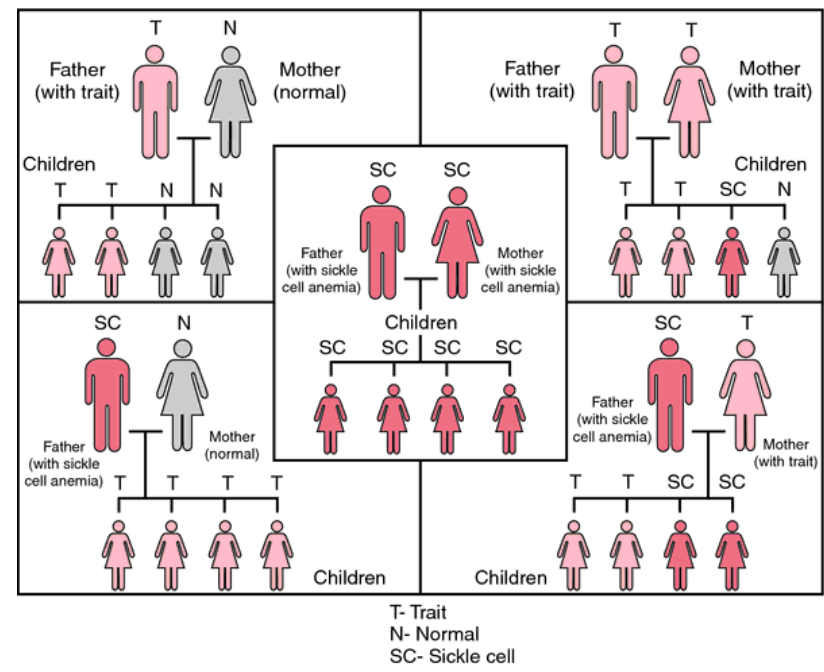

Fig. 1.2: Family chart

Fig. 1.2 depicts the possible combination and forth coming consequences whether the offspring will be a carrier (Trait), healthy (Normal) or diseased (Sickle cell).

As far as Chhattisgarh is concerned SCA is very prone to the forest areas and a particular race (entitle Sahu) is found to be more affected.

\section{Clinical aspects of sickle cell anaemia}

Impedance in blood vessels due to sickle- shaped blood cells produces major complications in the form of chain reaction. This abnormal condition produces periodic episodes of pain in the arms, legs, chest, abdomen and malfunctioning of vital organs. Symptoms include fatigue, yellow discolouration of skin, gum disease, respiratory infections and blindness in old age. ${ }^{2}$

In case of severe sickle cell anaemia, the percentage of sickled erythrocyte is found to be high. The symptoms may also include shortness of breath, heart palpitations, severe pain in the head and whole body specially muscle tenderness. ${ }^{3}$

Psychological and social factors pertaining to pain should also be taken into the account while examining the symptoms associated with the sickle cell anaemia. Thus mental retardation can also be considered as a symptom of SCA. ${ }^{4}$

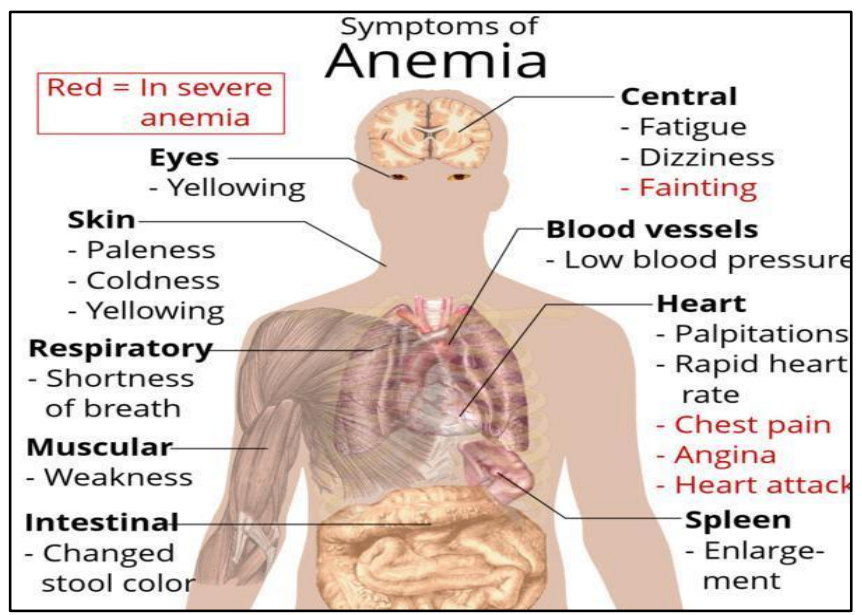

Fig. 1.3: Guiding symptoms of sickle cell anaemia

Some peculiar symptoms have also been reported in West African region. In this region sickle cell anaemia is associated with osteoarticular and non- osseous complications that imitate some surgical conditions. The most common complications include avascular necrosis, osteomyelitis and septic arthritis. ${ }^{5}$

\section{World wide spread of sickle cell anaemia}

Sickle cell disorder is supposed to be the problem of rural communities residing in different parts of World. Such areas are mostly found in under developed and some developing countries as well. West Africa is majorly affected, where it is considered as an endemic. ${ }^{6}$

Sickle cell anaemia is a common health threat in Sudan and in sub-Sahara Africa. Arabian Gulf countries and Indian peoples have also been suffering from this fetal complication for many years. ${ }^{7}$

Chhattisgarh state is known for its forest rich heritage in the World. Bastar, Sarguja region are reported as very susceptible area for sickle cell anaemia. The main reason behind it is malaria. It is due to this reason blood cells modify themselves into sickle shape and gives rise to sickle cell anaemia. 


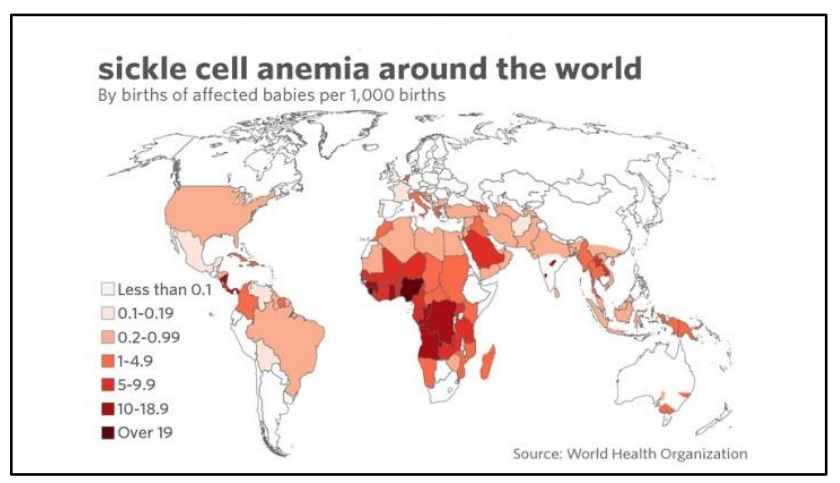

Fig. 1.4: Geographical status of SCA

\section{Impact of Allopathic System in the Management of Sickle Cell Anaemia}

Advancements in the allopathic system for diagnosis and care of SCA have increased the life expectancy of a person with SCA.

Currently drugs which are being used for the clinical management of sickle cell anemia include paracetamol, ibuprofen, hydroxyurea, penicillin, electrolyte fluids, deferoxamine and folic acid. In order to stabilize $\mathrm{Hb}$ level, blood transfusion is done. But such drugs causes severe side effects on prolong use. $^{8}$

A list of drugs (Table 1) along with their intended and side effect is given below.

Table 1: List of allopathic drugs and their pharmacological effect

\begin{tabular}{|l|l|l|}
\hline \multicolumn{1}{|c|}{ Drug } & \multicolumn{1}{c|}{ Symptoms } & \multicolumn{1}{c|}{ Side Effect } \\
\hline Paracetamol and Ibuprofen & Pain & Ulcer, Liver function impairment \\
\hline Hydroxyurea & Painful sickle cell crisis & $\begin{array}{l}\text { Increase risk of infection, Bone marrow } \\
\text { depression, Skin ulceration }\end{array}$ \\
\hline Penicillin & Infections & Resistance \\
\hline Electrolyte fluids & Dehydration & Cardiac arrest \\
\hline Deferoxamine & Iron Chelator & Dizziness \\
\hline Folic acid & Hb inducer & Abdominal cramps, Diarrhea \\
\hline
\end{tabular}

Hematopoietic stem cell transplantation (HSCT) may be the cure for SCA. Unfortunately, searching a perfect donor will be the most difficult task for HSCT.

\section{Intervention of herbal medicines for the management of SCA}

Allopathic medicines are gradually losing their credibility among peoples. It is happening just because of their fetal side effects. Medicines from plant origin are gaining popularity among consumers due to its no side effects. ${ }^{9}$

Yograj and Laxadi guguly are two Ayurvedic medicines have been tried clinically on 12 patients for the maintenance of hemoglobin level. The $\mathrm{Hb}$ count was surprisingly found to be increased in the treated patients. ${ }^{10}$

Nigerian folk medicine Vigna subterranean has been evaluated for its anti-sickling effect. In- vivo study has revealed its significant effect in the management of sickle cell anemia. ${ }^{11}$

In Democratic Republic of the Congo, a hundred of plants are used for SCA. These plants were evaluated through bio- guided assays. Three most active recipes were used for the formulation of an improved traditional drug called Drepanoalpha, of which scientific evidence is well established. ${ }^{12}$

Table 1.1: List of common herbs used in the management of $\mathrm{SCA}^{13 ; 14}$

\begin{tabular}{|c|c|c|c|l|}
\hline $\begin{array}{c}\text { Allium sativum L. } \\
\text { Part used: Bulb }\end{array}$ & $\begin{array}{c}\text { Garlic, } \\
\text { Lahsun }\end{array}$ & Liliaceae & Allicin & $\begin{array}{l}\text { Allicin has been shown to } \\
\text { enhance LDL oxidation and } \\
\text { to oxidize the iron of HGB in } \\
\text { RBC with methemoglobin } \\
\text { formation. It produces water- } \\
\text { soluble S-allylcysteine that }\end{array}$ \\
\hline
\end{tabular}




\begin{tabular}{|c|c|c|c|c|}
\hline & & & & $\begin{array}{l}\text { inhibits formation of dense } \\
\text { cells (Heinz bodies) in blood } \\
\text { samples from patients with } \\
\text { SCD }\end{array}$ \\
\hline $\begin{array}{c}\text { Aloe vera } \\
\text { Part used: Gel and leaf } \\
\text { extracts }\end{array}$ & Kumari & Liliaceae & Aloverone & $\begin{array}{l}\text { Shown inhibition of sickle } \\
\text { cell polymerization and } \\
\text { improvement of } \mathrm{Fe} 2+/ \mathrm{Fe} 3+ \\
\text { ratio of } \mathrm{HbS} \text { in the presence } \\
\text { of the extracts }\end{array}$ \\
\hline $\begin{array}{l}\text { Anacardium occidentale, } \\
\text { Part used: Leaves }\end{array}$ & Kaju & Anacardiaceae & Flavonoid & $\begin{array}{l}\text { Extract showed significant } \\
\text { reduction in polymerization } \\
\text { of deoxy } \mathrm{HbS} \text { molecules. } \\
\text { May be it resolublizes the } \\
\text { polymerize HbS }\end{array}$ \\
\hline $\begin{array}{l}\text { Cajanus cajan } \\
\text { Part used: seed }\end{array}$ & Arhar & Fabaceae & Phenylalanine & $\begin{array}{l}\text { Extract showed significant } \\
\text { reduction in polymerization } \\
\text { of deoxy HbS molecules and } \\
\text { may also involve in the } \\
\text { induction of fetal hemoglobin } \\
\text { production which causes a } \\
\text { reduction in bone pains } \\
\text { (painful crises), and may } \\
\text { ameliorate the adverseeffect } \\
\text { of sickle cell anemia on the } \\
\text { liver }\end{array}$ \\
\hline $\begin{array}{c}\text { Ceiba pentandra } \\
\text { Part used: Bark of trunk } \\
\text { and branches }\end{array}$ & $\begin{array}{l}\text { Saphed } \\
\text { semal }\end{array}$ & Malvaceae & Flavan-3-o & $\begin{array}{l}\text { Shown effect on other } \\
\text { symptoms of sickle cell } \\
\text { anemia like pain, } \\
\text { arthrosclerosis (digestion of } \\
\text { fibrin clot and plasma } \\
\text { clotting time) }\end{array}$ \\
\hline $\begin{array}{l}\text { Cymbopogon citratus } \\
\text { Part used: leaves, fruits }\end{array}$ & $\begin{array}{l}\text { Lemmon } \\
\text { grass }\end{array}$ & Poaceae & Terpenoids & $\begin{array}{l}\text { The extracts and oil of leaves } \\
\text { exhibited anti-sickling } \\
\text { activity. Mechanism of } \\
\text { action has been unknown. }\end{array}$ \\
\hline $\begin{array}{c}\text { Euphorbia hirta L } \\
\text { Part used: Whole plants }\end{array}$ & $\begin{array}{l}\text { Asthma } \\
\text { plant }\end{array}$ & Euphorbiaceae & Antho cyanins & $\begin{array}{l}\text { Reported to adsorb on } \\
\text { proteins and block the } \\
\text { polymerization of the desoxy } \\
\text { HbS in tactoids and reduce } \\
\text { sickling process and help to } \\
\text { improve RBCs sickle shape }\end{array}$ \\
\hline $\begin{array}{c}\text { Psidium guajavaFamily: } \\
\text { Part used: Leaves }\end{array}$ & $\begin{array}{c}\text { Jam, } \\
\text { amrood }\end{array}$ & Myrtaceae & Cinnamates & $\begin{array}{l}\text { Aqueous extracts showed } \\
\text { significant reduction in } \\
\text { polymerization of deoxy } \mathrm{HbS} \\
\text { molecules }\end{array}$ \\
\hline
\end{tabular}




\begin{tabular}{|c|c|c|c|c|}
\hline $\begin{array}{c}\text { Piper guineensis } \\
\text { Part used: Root, whole } \\
\text { plant }\end{array}$ & $\begin{array}{l}\text { Black } \\
\text { pipper }\end{array}$ & Piperaceae & Piperine & $\begin{array}{l}\text { Extracts have been reported } \\
\text { polymerization as part of the } \\
\text { mechanisms for its } \\
\text { antisickling action. That is } \\
\text { because it increased level of } \\
\mathrm{HbF}\end{array}$ \\
\hline Sorghum bicolor $L$. & Milo,jwari & Poaceae & Antho cyanins & $\begin{array}{l}\text { Anthocyanins block the } \\
\text { polymerization of the } \\
\text { desoxyhemoglobin S and } \\
\text { reduce hence the sickling } \\
\text { process, inducing the return } \\
\text { to the normal biconcave form } \\
\text { of RBCs }\end{array}$ \\
\hline picrorhiza kurroa & kutki & Plantaginaceae & Kutkin & $\begin{array}{l}\text { hepato-protective properties } \\
\text { and thus supports the liver } \\
\text { and spleen }\end{array}$ \\
\hline $\begin{array}{c}\text { Plumbago zeylanicaPart } \\
\text { used: Roots }\end{array}$ & Chitrak & Plumbaginaceae & $\begin{array}{l}\text { Anthra } \\
\text { quinones }\end{array}$ & $\begin{array}{l}\text { Crude methanol extract and } \\
\text { its aqueous fraction in } \\
\text { vitro anti-sickling activities. } \\
\text { It also affect their mean } \\
\text { corpuscular volume (MCV) }\end{array}$ \\
\hline $\begin{array}{c}\text { Aegle marmelosPart used: } \\
\text { fruit, leaves }\end{array}$ & bael & Rutaceae & Angelicin & $\begin{array}{l}\text { HbF (Fetal Hemoglobin) } \\
\text { inducer }\end{array}$ \\
\hline $\begin{array}{l}\text { Carica papayaPart used: } \\
\text { Unripe fruits or leaves }\end{array}$ & papaya & Caricaceae & $\begin{array}{c}\text { Carica } \\
\text { pinoside }\end{array}$ & $\begin{array}{l}\text { Shown inhibitory action on } \\
\text { the hemolysis of RBCs }\end{array}$ \\
\hline
\end{tabular}

In Chhattisgarh state, there are about 56 plant species reported for anti-sickling property. These plant species are distributed all over the state.

\section{Traditional Herbs of Chhattisgarh}

Majority of population rely on traditional herbs in Chhattisgarh. We have interviewed and discussed with tribal and traditional healers, who are engaged in the treatment of sickle cell anemia. They have informed us about few herbs which are being not reported as antisickling plants.

We have only assessed the phytochemical screening of such herbs. Moreover, we have found the resemblance in chemical constituents with reported herbs. Brief profiles of those traditionally used herbs are as followed

Asparagus adscendens Roxb is a natural occurring plant in Chhattisgarh region, also found in adjacent states. This herb has been used in many indigenous system of medicine for years ago. Active compounds present in asparagus are well known for their multiple health benefits because of presence of ingredients like proteins, alkaloids, saponins and tannins. This in turn helps in improving fertility and vitality in women and men. Active composition enriched in asparagus calms down nerve cells and prevents the risk of nervous disorders like depression, anxiety and stress. ${ }^{15}$

A study of ancient Ayurvedic literature has claimed that Asparagus racemosus have numerous medicinal and therapeutic properties like phytoestrogenic, antidepressant, antidiarrhoeal, anticancer etc. It has been specially recommended in case of threatended abortion, galactogogue as well as restorative action as it is beneficial in women's complaints. It is used in almost 67 Ayurvedic preparations. The major active constituents are steroidal saponins named as shatavarin I and shatavarin IV. A new antioxidant compound named Racemofuran, together with known compounds 
asparagamine A, and racemosol. Three steroidal saponin namely Racemosides A, B and C were isolated. Earlier reported isoflavones, steroidal glycosides, polycyclic alkaloids and a dihydrophenanthrene derivative were isolated from roots. $^{16}$

Holarrhena antidysenterica is commended for the medicinal applications of its stem bark, leaves and seeds in Ayurveda. During the past century, studies on the pharmacological nature of the plant have yielded important properties associated with the plant viz. analgesic, antibacterial, anti-diarrhoeal, anti-amoebic, anti-inflammatory and anti-haemorrhoidal activities. Moreover, recently some other properties have also been discovered viz. antimalarial, anti-diabetic, antioxidant, anti-urolithic, anti-mutagenic, CNSstimulating activity. Most of the known chemical constituents have been found in the stem, bark, leaves and a few in the seeds as well. The major constituents are steroidal alkaloids, flavonoids, triterpenoids, phenolic acids, tannin, resin, coumarins, saponins and ergostenol. $^{17}$

Terminalia chebula is one of the most commonly used plants in traditional systems of medicine in Indian sub-continent. It is called the 'King of Medicine' in Tibet and is always listed at the top of the list in Ayurvedic Materia Medica due to its extraordinary power of healing. In Terminalia chebula, $33 \%$ of the total phytoconstituents are hydrolysable tannins (which may vary from 20-50\%) and are responsible for pharmacological activity. These tannins contain phenolic carboxylic acid like gallic acid, ellagic acid, chebulic acid and gallotannins such as 1,6 di-O-galloyl- $\beta$-D-glucose, 3,4,6 tri-O-galloyl- $\beta$ D-glucose, 2,3,4,6 tetra-O-galloyl- $\beta$-D-glucose, 1,2,3,4,6 penta-Ogalloyl- $\beta$-D-glucose. Ellagitannin such as punacalagin, casurarinin, corilagin and terchebulin and others such as chebulanin, neochebulinic acid, chebulagic acid and chebulinic acid reported in literature. The tannin content varies with the geological variation. Flavonol glycosides, triterpenoids, coumarin conjugated with gallic acid called chebulin, as well as phenolic compounds were also isolated. Terminalia Chebula has a strong effect against the wound healing, has antibacterial activity, and exhibits strong cardio protective. Terminalia
Chebula also has antioxidant components, which indicates it can increase the life of tissues. Further few studies shows the anti-tumor activity of Terminalia Chebula and another study shows that it has considerable effect in inhibiting the HIV virus which ultimately results in AIDS. There is a substantial evidences found that, it can be used as gastrointestinal motility agent, Anti-aging substance. It also possess properties like Antilithiatic activity, Hypolipidemic activity, Radio protecting Ability, Antifungal activity etc. $^{18}$

\section{Conclusion}

The major phytochemicals in plants used for the management of SCA. The classes of these metabolites include phenolics (hydroxybenzoic acids and its derivatives, coumaric acid derivatives, etc.), polyphenolics (flavonoids, anthocyanins, tannins, etc.), anthraquinones, limonoids, alkaloids (urea and guanidine alkaloids, piperidine alkaloids, amide and amine alkaloids, etc.), terpenes (diterpenoids and pentacyclic triterpenoids, etc.) carbohydrates. The activities of some of these plants have been scientifically verified, and the major or active metabolite responsible for the observed activity identified. From the profile of chemicals, it is observed that even those plants not possessing antisickling effect are still very useful as they help to relief pains and probably reduce inflammation and other complications associated with SCA. However, it is obvious that most of the active chemicals have antioxidant activity. Hence, the molecular and metabolic roles of antioxidants in SCA management need to be properly investigated. Amongst plant metabolites, phenolic and polyphenolics are known to possess excellent antioxidant activities, and may play significant role in SCA management. ${ }^{19}$

\section{Source of Funding}

None.

\section{Conflict of Interest}

None. 


\section{References}

1. Kaur M, Dangi CB, Singh M. An overview on sickle cell disease profile. Asian J Pharm Clin Res 2013;6(1):25-37.

2. Otoikhian CS, Okoror LE. Sickle cell disease African killer: Biologists Alternative. Int J Pharm Med \& Bio Sci 2012;1(2)

3. Sahu M, Singh V, Yadav S, Harris KK. Plant extracts with antisickling properties: A feasible succor towards sickle cell disease management - A mini review. J Phytol 2012;27;4(3)

4. Williams H, Tanabe P. sickle cell disease: A review of nonpharmacological approaches for pain. J Pain Symptom Manag 2016;51(2):163-77.

5. Vaishya R, Agrawal AK, Edomwonyi EO, Vijay V. Musculoskeletal manifestations of sickle cell disease: A review. Cureus 2015;7(10).

6. Ameh SJ, Tarfa FD, Ebeshi BU. Traditional herbal management of sickle cell anemia: Lessons from Nigeria. Anemia 2012;8:2012.

7. Elamin A. Current trends in the management of sickle cell disease. Sudan J Med Sci 2007;2(2):129-38.

8. Imaga NA. Phytomedicines and neutraceuticals: Alternative therapeutics for sickle cell anemia. Sci World J $2003 ; 14 ; 2013$

9. Imaga No. The use of phytomedicines as effective therapeutic agents in sickle cell anemia. Sci Res Essays 2010;5(24):3803-7.

10. Panigrahi HK, Kushawa H, Sharma SS. Treatment of sickle cell disorders by Ayurvedic medicine. Anc Sci life 1997;17(1):15.

11. Simeone EI, Tufon EN, Victor oN, Noel NN. Antisickling potential of the ethanol seed extracts of Vigna unguiculata and Vigna subterranean. Int J Biochem Biotechnol 2012;1(9):226-9.
12. Gbolo BZ, Asamboa LS, Bongo GN. Bioactivity and chemical analysis of Drepanoalpha: An antisickle cell anemia poly herbal formula from Congo- Kinshasa. Am J Phytomedicine Clin Ther 2017;5:1

13. Vaishnava S, Rangari VD. A review on phytochemical and pharmacological research- remedy for sickle cell disease. Int J Pharm Sci Res 2016;7(2):472

14. Gupta A, Sharma S, Verma HK, Tyagi DS, Mishra PK, Patra $\mathrm{P}$ et al. Phytochemical characterization of twelve medicinal plants used for sickle cell disease management in Chhattisgarh. Int J Pharm Bio Sci 2015;6(2):1062-70.

15. Thakur S, Sharma DR. Review on medicinal plant: Asparagus adscendens Roxb. Int J Pharm Sci Health Care 2015;5(3)

16. Choudhary D, Sharma D. A Phytopharmacological Review on Asparagus racemosus. Int J Sci Res 2014;7(3).

17. Vashishtha A, Sinha S, Sharma A, Reddy PH, Rathi B, Prasad NVSRK et al. Evaluation of phytochemical and pharmacological aspects of Holarrhena antidysenterica (Wall.): A comprehensive review. J Pharm Res 2013;6:488-92.

18. Rathinamoorthy R, Thilagavathi G. Terminalia Chebula Review on Pharmacological and Biochemical Studies. 2014;1(6):97-116.

19. Omoregie EH, Folashade KO. Chemical constituents and biological activity of medicinal plants used for the management of sickle cell disease - A review. 2013;7(48):3452-76.

How to cite this article: Dash DK, Sahu A, Panik R, Mishra K, Kashyap P, Tripathi V. Comparative screening of anti-sickling reported and traditional herbs found in Chhattisgarh. Int $J$ Pharm Chem Anal 2019;6(4):88-94. 